\title{
Linguistic Imperialism: A Critical Study
}

\author{
Paula González Fernández \\ University of Oviedo \\ paugf@yahoo.es
}

\begin{abstract}
Today, there is a rising need of an international language for infinite purposes and, so far, English seems to be that language. However, its use is being discriminative and unfair in different aspects. These have been discussed in the academic circles, but little is being considered of the general public's ideas. Furthermore, the different consequences that the notion of Linguistic Imperialism has, and all the various issues mentioned in the scholarly debate, do not seem to reach far beyond the academic spheres.

The main goal of this study is to deal with perceptions of English Imperialism. Due to space limitations, we cannot present here the whole study. Hence, we will concentrate on the spread of English in the world and the agency behind it. We will first revise the opinion found in the literature, of scholars and linguists, to concentrate later on the feelings of the general public. To this end, we will use data collected both through a questionnaire and some personal interviews. The comparison of the two sources will show that what is being discussed by many authors is not generally reaching the general public and that the latter's opinion is rather complex and inconsistent, with little linguistic awareness.
\end{abstract}




\section{Literature review}

\subsection{English in the world}

If we take a look at the linguistic map in the world today, English spreads all over the globe. It is spoken in 105 countries (URL: Ethnologue, 2005) and it has a special status in more than 70 countries (McKay, 2002).

McArthur (1998) gives an account of different representations of English in the world. Of these, Kachru's (1986) representation is probably the most renowned:

-The Inner Circle are countries where English is the Native or major Language -ENL. Recent estimates suggest that 377 million people speak English as a first language -“native speakers" (henceforth, NSs) (Crystal, 1997).

-The Outer Circle could be related to countries where English is the Second Language -ESL, with a long history of institutionalised functions. The estimate often quoted is 508 million (URL: Ethnologue, 2005). English is the official or joint official language of over 70 countries, but in some of these, the language is barely used by the majority of the population.

-Finally we have the Expanding Circle, where English is studied as a Foreign Language -EFL. Estimates range from 300 million to 750 million. Such figures can only be treated as approximate. There is no way of quantifying the number of people worldwide who may have learnt some English at any point in their lives. NNSs.

These last two circles correspond to the "Non-Native Speakers of English" or

What should be clear from this classification is that the number of non-native speakers of English already outnumbers that of its native speakers. Besides, nowadays we can find ENL speakers in ESL and EFL territories, and vice versa (McArthur, 1998). Furthermore, in many EFL countries there are more English-speaking bilinguals than in other ESL nations (McKay, 2002).

\subsection{International language(s)}

The position of English in the world today, and the uses we make of it, give English the status of the language for international communication worldwide. Besides, it is used between individuals of the same country (e.g. India) and therefore, it is an "international language in both a global and a local sense" (McKay, 2002: 5). Among many other colonial languages, only English has had the economical and military power necessary to become the international language (McArthur, 1998; Davies, 1996).

There have been attempts to create other variants, like treated natural languages (e.g. BASIC, Nuclear, Utilitarian) or other movements like the Plain English Campaign (Crystal, 1988), Redish's Plain English Movement (1985) or the Society for Pure English. But they all have English as a basis.

When characterising English as an International Language, we can find divergent 
approaches in the literature. The main discrepancies arise when considering the role of the different varieties of English and written and spoken forms and reduced codes (Airspeak or Seaspeak) (Davies, 1989, Widdowson, 1997). For a more detailed account of the role these varieties, see González Fernández (2004).

Artificial languages have also been created for international communication, in order to counter-balance the privilege given to native speakers of a natural language. Of these, the most successful one in history has been Esperanto, which has become a natural language for many speakers. It favours international communication on equal terms and even has learning benefits (Phillipson, 2000; Skutnabb-Kangas, 2000; González and González, 2004).

\subsection{Imperialism}

Linguistic imperialism. English in the world.

For many scholars, the position of English in the world is not accidental. The subject of linguistic imperialism was raised in different works especially during the late 1970s and 1980s (Greenbaum, 1985; Kachru, 1981, 1986; Phillipson, 1988; Quirk and Widdowson, 1986). However, Phillipson's book (1992) gave it a name and provoked a heated debate that still continues in the scholarly circles.

The agency behind the spread of English is differently understood by many. The most important milestones have been the role of the British Empire in the $19^{\text {th }}$ and $20^{\text {th }}$ centuries and of the US after the Fifrst and Second World Wars. The importance given to these varies from author to author.

On the one hand, authors like Crystal (1997) believe that English was just "at the right place at the right time" (ref. in Phillipson, 2000: 105). Although there was some kind of control behind the spread of English in the first moments of colonialism, that is not the case nowadays, Crystal explains. It seems to pose no danger and furthermore, it is presented as an inexpensive panacea against multilinguism. From this point of view, those who chose to speak English nowadays do so freely. Brutt-Griffler $(1998,2002)$ follows a similar approach in her description of World English.

On the other hand, many agree with Holborow in that "the spread of English remains inextricably interwoven with its economic and social origins" (Holborow, 1992: 358). The role that certain nations have played since the end of the Second World War is also undeniable to Ricento (1994). In the same line, Phillipson's work (1992) is a deep study of the organisations and the governments that, directly or indirectly, have supported the spread of English. As he confirms in other work, English is "second in importance to the British economy after the North Sea oil" (Phillipson, 2000: 90). Furthermore, authors like Ngugi (1993) or Pennycook (1994, 1995, 1998, 2000a, b, c) attribute a lot of importance to the resistance opposed to it from Third World Countries. The political implications -and causes- of the spread of English, which Pennycook calls the "structural power of English" (2000b: 108), are an unquestioned belief for him, a covert and subtle type of imperialism. 
Together with Skutnabb-Kangas $(2000,2002)$ and Canagarajah $(2000)$, he is one of the few scholars who give a promising solution to the current state of languages and identity problems related to languages. According to these authors, a better educational system, and better educational practices, could substantially help to ease many of these problems. Education should acknowledge linguistic human rights and make the individual critical with the reality that surrounds him/her. Skutnabb-Kangas (2000) offers a deep analysis of various forms of language planning in education and their relevance beyond the school premises. But this is not the panacea and linguistic human rights should be present in all state policies.

Discourse Imperialism. The world in English.

Pennycook establishes a clear difference between what Phillipson (1992) called Linguistic Imperialism -or what Pennycook prefers to name English in the world (1995), and Discourse Imperialism, or rather the world in English. The former is the (deliberate) spread of the English language itself, with the oppression it brings, while the latter refers to the expansion of a certain Discourse dictated by the West, mainly by white men, but, most importantly, a Discourse written in English, which guarantees the supremacy of some countries over others. This form of imperialism is much subtler and, therefore, dangerous (Phillipson, 1992). Such a Discourse is the source of regular inequalities in all fields: economics, politics, education, culture and communication. English expands hand in hand with it, it is the "language of international capitalism" (Pennycook, 1995: 43). His view of the spread of English does not let him see this language as something beneficial and neutral, but as something related to much discrimination in our world (1994). Besides, Tollefson (2000) seriously questions the benefits that English may bring to the individual.

In the same light, Fairclough $(1989,1992 \mathrm{a}, 1992 \mathrm{~b}, 1995)$ gives great importance to discourse in power relations. The development of capitalism since the $19^{\text {th }}$ century has been essential for defining our society nowadays. Having moved towards a capitalist society, everything is in the hands of multinational companies, and is regarded as a commodity. So is English. Fairclough gives a great importance to discourse and the use it makes of language, since social interaction of all kinds is carried out through language. Therefore, "power relations are (...) exercised implicitly in language" (1992a: 6). We are now witnesses of power in and behind discourse (1989:43). Power in discourse implies that there is some kind of domination in the message, in the text (oral or written) as such: there are constrains on who can say what to whom. But Fairclough, by talking about power behind discourse also identifies domination at a higher level, in the society itself where the text was produced: "the whole social order of discourse is put together and held together as a hidden effect of power" (1989:55). In this case, we are talking of hidden forms of control, which lead to hidden imperialism.

Skutnabb-Kangas's work (2000) follows the same line of thought. Hers is a book which follows a holistic approach and provides the reader with a rich source of documents and first-hand reports. She is highly critical towards the role of English in a globalised world, 
especially when it is at the root of much injustice, identity and educational problems, not to mention what she calls "linguistic genocide".

All in all, it should be clear by now that we are not talking of a complot theory behind the expansion of English. To some extent, its position in the world nowadays is the result of a series of interwoven factors and a "complex process brought about by those who actively promote the language and those who consciously choose to learn it" (McKay, 2002:24). No language is considered imperialistic, nor sexist or racist. We agree with Fairclough $(1989,1992 \mathrm{a}, 1992 \mathrm{~b}, 1995)$ on how closely related language and society are. A language is only a mirror reflecting the structure behind it and we should rather talk of Discourse Imperialism, as Pennycook suggests in his various works. English, then, could be a useful tool if it were learned additively within the frame of language ecology (Skutnabb-Kangas, 2000).

\subsection{Ownership of English}

To own a language is to be able to affirm oneself through it and to adapt it to your own meaning and wishes (Widdowson, 1994).

As we have seen, the majority of the users of English nowadays are non-native bi/multi-lingual speakers. Therefore, English, when used at international level, i.e. EIL, should not be considered British anymore. That is the price English has to pay for becoming an International Language (Romaine, 1992). This has important consequences for the establishment of standards of EIL. Standard British English or standard American English cannot count anymore as the languages for international communication. Likewise, even if other varieties of English were fully recognised and standardised, their status should be the same as those of British or American English. Furthermore, if English really belongs to all those who use it, for a myriad of purposes, then the establishment of its standards as a language for international communication should not be in the hands of NSs alone. Instead, it should be in the hands of those who use it and accommodate it to their own meanings and benefits. The use of an international language in the world should benefit all its users and not just a few.

However, Pennycook (1998) challenges this view of worldwide ownership since those transformations have still not been made. This and other concepts -such as, for instance, the various fallacies mentioned by Phillipson (1992) - are still in use and defended by people formed in the TESOL ${ }^{1}$ environment and other universities for the teaching of languages (González Fernández, 2004).

\subsection{English as an international language}

In her book, McKay (2002) holds that as far as an international language is concerned:

a) its learners do not need to internalise the cultural norms of native speakers of that language,

b) the ownership of an international language becomes 'de-nationalised', and 
c) the educational goal of learning it is to enable learners to communicate their ideas and culture to others (McKay, 2002:12).

Therefore, an international language serves the goal of giving its speakers the capacity to communicate globally with speakers from other countries, or locally, within their own country, as was seen above. It should therefore be detached from any cultural norm and its learners should not need to imitate any native speakers (in the case of a national language like English). Whatever the standard might be, we would not need NSs to tell us what the norm is.

However, English has seriously been criticised as an unfair international language. According to Pennycook (1994, 1995), Ricento (1994), Crystal (1997) and SkutnabbKangas (2000), it triggers many injustices, which can be grouped as follows:

It acts as a gatekeeper for education, jobs and social mobility, favouring a monolingual elite, both in the Centre and in the Periphery.

It "makes certain domains inaccessible to many people" (Pennycook, 1994: 13).

It is causing many minority languages to disappear and prevents many people from identifying with their mother tongue.

It hinders literacy in the mother tongue for speakers of minority languages.

It is not receptive to the needs of many people.

It privileges the figure of NS in the ELT profession, together with many other fallacies (Phillipson, 1988, 1992; Kachru, 1992).

Although English is not the only source of these problems, as linguists, we cannot remain neutral (Phillipson and Skutnabb-Kangas, 1996; Davies, 1996). Much is being discussed by numerous scholars concerning the role of English, but we should consider if probably more should be done in order to reach beyond the academic circles.

Furthermore, the learning of any international language should be additive and not subtractive (McKay, 2002, Skutnabb-Kangas, 2000), but this seems not to be the case with English (Skutnabb-Kangas, 2000).

\section{Methodology}

As was said in the introduction, the aim of this study is to analyse people's attitudes about the role of English in the world and to compare it against what is being discussed in the scholarly spheres.

The main source of data for the investigation was a questionnaire in English (see Appendix 1), distributed via electronic mail, medium which offers a wider range of responses than a face-to-face survey.

The interviews (see Appendix 2) were effected to go deeper into people's feelings and explain what the questionnaires could not make clear. At the end of the interview all the 
subjects were eager to continue talking about the issue. Therefore, the recording continued, since it was then that the most interesting remarks would be mentioned.

One step not to be taken for granted in this procedure is to ask for permission to be interviewed and recorded, and to ensure the subjects that, above all, anonymity is going to be preserved, both with the questionnaires and with the interviews. This was done by means of a letter sent together with the questionnaires via email (see Appendix 3), and, in the case of personal interviews, by explaining before what the investigation was about and other details about the procedure of the interview.

Due to the nature and goals of our survey we are not trying to give arguments in favour or against any theory. The samples were not representative of any population -in many cases there was only one individual from some countries. Besides, we are dealing with an elite. The majority of the informants have a good or perfect command of English and knowledge of other languages -sometimes not only their mother tongue; they also have access to email and, generally, a university degree. Although they cover both genders, and they do not belong to a single age group, they were in general university students. Taking all this into account, a qualitative approach was followed.

Consequently, no independent/dependent variables were selected in the questionnaires. Although the informants' profession, age and country of origin/residence have been taken into account, together with their knowledge of other languages, these factors are only relevant in certain questions.

We are dealing with a mixture of a purposive sampling -people the questionnaires was directly sent to- and a snowball sampling -people to whom the questionnaire was forwarded later by other informants. Therefore, it is impossible to say the final number of questionnaires sent.

As regards the interviews, the informants tended to relax after the first minutes. Therefore, the first minutes of the recording were ignored (introductory questions). They all tended to be quite nervous in the initial part, just limiting themselves to giving mere facts, without openly expressing their opinions about them.

All in all, 11 interviews were conducted. The language used was (British) English, with the exception of one, in which the interviewee preferred to use Spanish.

\section{Questionnaires}

As has been said, all the informants who filled in the questionnaires had access to electronic mail and they belonged to middle/upper classes. Those who were not still university students had already developed a good career. They belonged to both genders and the ages went from 19 to 73 years old.

In the chart below, 10 questionnaires are missing from the total received. Of those, nine belonged to Dutch individuals. They were ignored since the person who first received the questionnaire, filled it in and forwarded it without previously deleting his/her own answers. Therefore, these subsequent questionnaires were considered to be strongly biased. The tenth questionnaire was disregarded since the answers showed $\mathrm{s} / \mathrm{he}$ had not taken the area 
under discussion seriously enough. All in all, the number of questionnaires considered was as follows:

\begin{tabular}{|cccc|}
\hline Nationality & Number & Living in England & Teachers of English \\
\hline Group A & 17 & 14 & 2 \\
Group B & 10 & 2 & 0 \\
Group C & 8 & 8 & 1 \\
Group D & 16 & 9 & 1 \\
China & 3 & 3 & 2 \\
Mexico/Argentina & 16 & 9 & 1 \\
\hline Total & 123 & 70 & 17 \\
\hline
\end{tabular}

The questionnaires were grouped according to the countries of origin, and their political background. For some questions, it would be more informative to classify them taking the language of literacy as a reference; or considering the informants' country of residence -the UK or other, or their profession (ELT teachers).

Group A countries were former colonies of the British Empire, or territories occupied and/or protected by the US: Singapore, Malaysia, Syria, Egypt, Turkey, Mauritius, Cyprus, India, Taiwan and South Korea and Lebanon. Although not all of them follow the same political pattern, they all use English as a medium for instruction and could be classified as ESL countries.

Group B countries are those which have more and more literacy in English, especially at University level: Belgium, Holland, Finland.

Group C stands for countries which belonged to the former Eastern Block, and which now start to have literacy in English as a symbol of prestige: Poland, Macedonia, Romania, Ukraine, Hungary, and Yugoslavia.

Group D brackets together countries from Central and South Europe, which have little literacy in English, if any. Many have been colonial powers themselves, although not all of them: Spain, France, Italy, Portugal, and Greece. Germany seems to match other Southern European countries when it comes to the literacy tradition in their own language.

\section{Interviews}

Eleven interviews were conducted with people of different nationalities, genders, ages and professions. Their countries of origin were Taiwan, Syria, China, Mexico, Singapore, Macedonia, France, Isle Reunion, Zimbabwe, Rwanda and Italy. Special attention was put in selecting the nationalities, depending on whether they were former colonies of any Empire, countries with literacy in a second language which is not theirs (e.g. English) or European countries. They were all tape recorded. They all belonged to the middle/upper classes in their countries of origin and they have a good command of English and a university degree. 


\section{Results ${ }^{2}$}

\subsection{English as an international language}

- The issue was raised in the questionnaires as an open question, considering the public attitude in their country towards English. ${ }^{3}$

People coming from France or former French or Spanish colonies saw French or Spanish as another potential international language. Nevertheless, they were not aware of actions like the "English Only" movement, which is gaining a lot of strength in the US (URL: US English Inc., 2005).

Some of the informants talk about the importance of English in their countries of origin:

For the majority it is not a problem because there is a feeling that if you learn it, in a way you'll be empowered yourself -it, of course, being the only language needed in the whole world to make yourself understood.

Others have a negative view of why this is happening, and their point of view is related to the issue of covert imperialism:

It's related to the issue of globalisation and one of their best achievements: make us believe on its inevitability.... Naturally, people who pay attention to this fact of globalisation and it own exclusion with the new order of neoliberalism has a negative attitude towards English, of course. No one likes a foreign language, culture or country, which is also simpler, not as rich as yours, cold and instrumental, to be the language that the world speaks. But it is a phenomenon that apparently draws little attention.

For others, it is a positive tool:

I don't think people in my country are aware of the fact that English is a powerful language. They look at it as a means of getting them better job prospects and a chance to go and live abroad.

A few informants describe a scission in their society:

Young people agree with learning English (because they consider it very useful), but the old generations strongly disagree.

The general opinion of the informants is then not uniform. It should be noted that those whose mother tongue is protected and extended in the world nowadays -e.g. French or Spanish, tend to defend it. English is generally considered as a useful tool and not everybody relates it to the power of the US. In many countries, a division can be appreciated in the society. Older generations seem to be more defensive about their 
language and culture, of the local and traditional. Contrarily, younger generations, more exposed to popular culture and who have lived a different political situation, tend to have a high regard for English, relating it to modernity and progress.

- Another topic mentioned in the interviews was the role of English as the language for international communication.

Interviewer (I): Should it be another one or, do you think, like Esperanto, French, German...?

Tw: Well, it would be nice, but I think it's difficult because... especially in Far East, no many people learn any other language because English is the only way, only language in common.

Syria (S): I'm not saying it should be but it's a fact of life now. ... I don't see the reason behind the change for another language.

Mexico (Mx): Bueno yo creo que sí es. Depende ahora qué tanto va a seguir la la lengua inglesa porque si te das cuenta el español es el mayor número de países que hablan español; los chinos, hay muchos chinos eso significa que la mayoría de la gente habla chino en cantidad. Pero los países que hablan español están tomando, como que va a ser la primera lengua en el futuro, porque también EEUU que es el país que contiene mayor número de angloparlantes, la mayoría hablan ya español.

Mx: Well, I think so. It depends though how long that will be so cos if you think about it, Spanish is the there's a larger number of Spanish-speaking countries; the Chienese, there's lots of them which means that most of the people speak Chinese. But the countries where Spanish is spoken are getting, it looks like it's gonna be the first language in the future, cos even the US which is the country with most of English-speaking people, most of them already speak Spanish.

China (Ch): I think English mostly is the international because different countries they all learn English and maybe because America now, the English is the official language in America and America is the strongest country in the world they have a lot of influence in through the different country through the globalisation.

Opposing points of view can be seen in these answers. Although they are a minority, some seem to acknowledge some agency behind the spread of English, and they normally disagree with it, but they see no means to confront this political power. The same applies to the English language and its power, and "there is nothing we can do about it", as the French respondent indicated. Even in the few cases where there is critical awareness of the situation, little changes seem to be taking place. But the general tendency is to consider English a useful and needed tool for various reasons. The relation between language and political power will be more directly addressed below. 


\subsection{Linguicism}

- English as a gatekeeper

The question of English being a gatekeeper for working opportunities was addressed in the questionnaire ${ }^{4}$, with the following results:

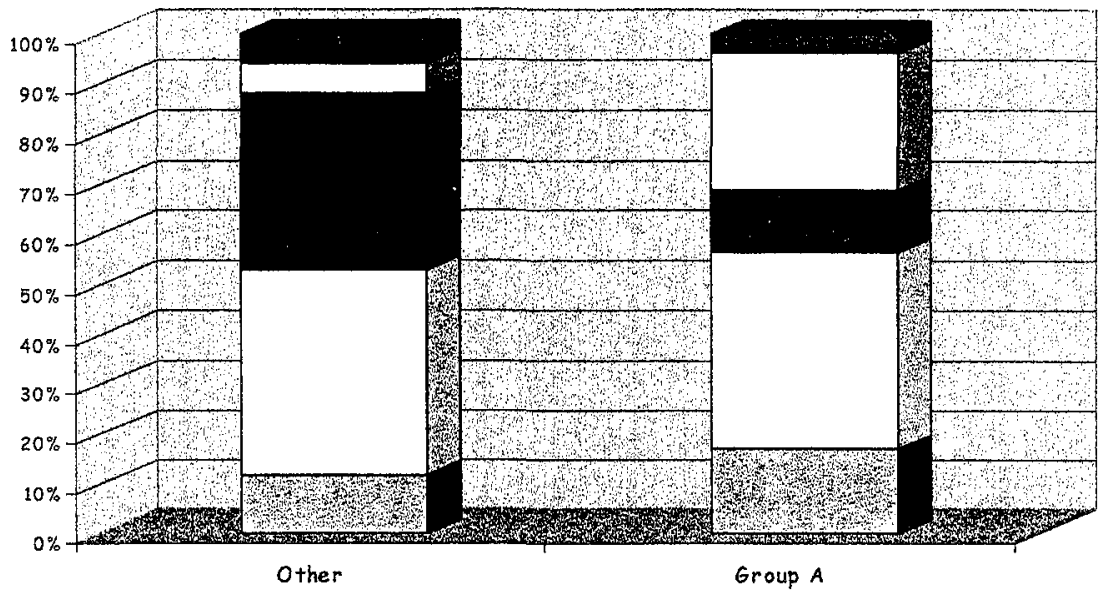

$\square$ Strongly agree $\square$ Agree Neutral $\square$ Disagree Strongly disagree

Whereas in the first column there is a clear division between those who think that English can be discriminative and those who remain neutral, in the second column (Group A countries) the tendency is more radical, either agreeing or disagreeing with the statement. The interviews can help to clarify these divisions:

France (Fr): For the job I want to do, as I would like to teach English, but: otherwise, no, as long as I can communicate.

Macedonia (Mc): Well if, for example you: try to speak English but you are not very successful, and: let's say you go for a job, whether in this country or at home, the person who would speak better English would have better chances even though you might have other skills.

Reunion (Re): It is because if you know English you can come here in England and have a job pretty easily and that in many fields at university, you wouldn't have in France, you wouldn't have that in Spain, if you come here to work at the university, or if you come to do a $\mathrm{PhD}$ or whatever you'll find it easier, so... I don't know if you call it discrimination but it'll be a weakness not to have English, definitely. 
Italy (It): Yes it is. Well it's normal, I think, you go to apply for a job, even in Italy, I put in my curriculum that I speak English, I have more chance than another person to have the job, but it's also true that if I go to apply for the same job and I put in my curriculum that I'm specialised to use particular machine I have more chance of another person that is not specialised.

S: It's just logic that if you are qualified from England, you: cannot be matched with a person who is qualified, the same degree in my country ... but that puts lots of limits and reduces the chances for: everybody so this is what I say, it's unfair.

Rwanda (Rw): I think it can become (...) an excuse for discrimination, but discrimination doesn't come from the language, it comes from not understanding the person, the people or where they come from. And using the language as a way of excusing that a lot of employers may dismiss a candidate because they say "they don't have good communication skills or: a good command of English", when really what the problem is their background, not the language, they may be capable, not as good as the English person but capable of communicating.

Rw: People in Kenya and in Rwanda just have come to terms with it, a lot of them would want to get a good education, and wanted to work, to get good jobs and to do that you tend to have to study in English, maybe: come here in you know, to England or to the US to study.

Zimbabwe (Z): Say for instance one wants to study medicine, and definitely English is very important, do you get the point? but he's a brilliant young guy, very good at mathematics, very good at science, but can't speak English, or he's not good at English, he's not going to fulfil his ambitions because he performed poorly in English. But if had been in his own language he'd have been a good doctor.

An Argentinean added this in his/her questionnaire:

Given that the cost of studying English is not affordable for many people, not everybody has the opportunity to learn it.

Such an affirmation is in line with Pennycook's claim that access to discourse in English is restricted. If there is a Discourse imperialism, as we shall see, and that Discourse is written in English, only those who could have access to it -and therefore, those who know English- would be able to change it.

\subsection{Linguistic imperialism?}

At this point, we directly asked the informants if they consider that there is a close link between English and the political and economical situation in the world nowadays.

- "The economic and military power of the USA is the main reason for the rapid spread of English". 


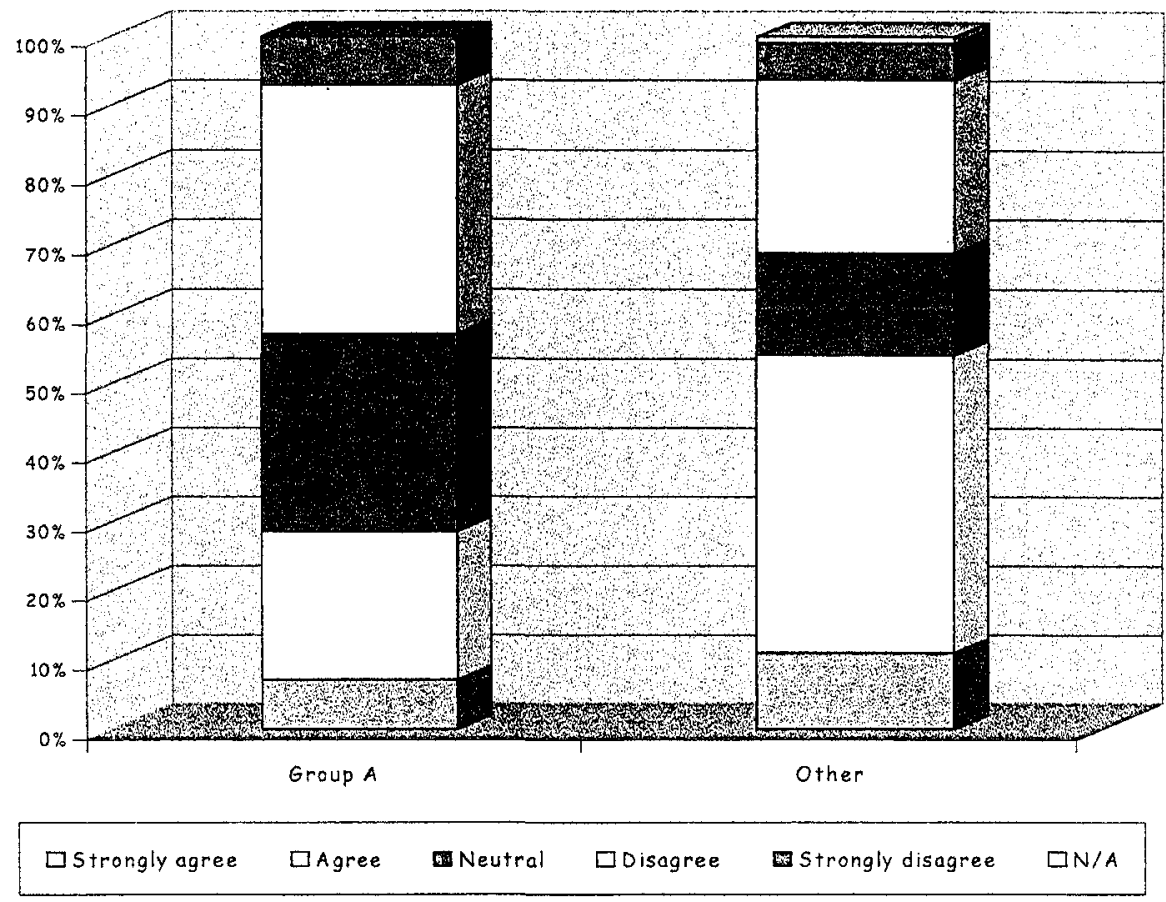

We can notice a big difference between both columns. Informants from countries belonging to Group A did not seem to correlate these phenomena, whereas those coming from other countries are more eager to identify both expansions. The interviews also show this difference in opinions:

It: Of course, the Americans. But I think it's normal for how the things, the way they are going now we've to understand that the country that benefies more is the: American country, no? it's not, I think that the point is not the English imperialist, is the American imperialist, that scares me more, personally.

Mx: Bueno (risa) es obvio, ¿no? influencia americana, inglesa británica, económicamente...

Mx: Well (laughter) it's obvious, isn't it? American influence, British, economically...

And a Mexican informant added the following in his/her questionnaire:

Most people are aware of the economical and political influence of the USA in Mexico and this 
is the engine of the interest paid to the language. In Mexico there is a popular expression that provides a good idea about the public attitude to this country (the country, but not the language): "Pobre Mexico, tan lejos de Dios y tan cerca de los Estados Unidos". Poor Mexico, so far away from God and so close to the US.

S: But I mean, being an international language there has been a reason for this, the dominance of English, or the spread of English, you see the influence of the Americans after the second World War, their dominance of the economy and all that, you know, just made it, gave actually way to the success of English. Now, the difference in technology as well, recent in communication, and in science, this development gave a lot of help to the English language to be widely spread. So that doesn't mean that I justify the replacing my language.

Re: Well, that means actually, well, no, I don't think so because in that case everybody will try to speak English with an American accent, no? which is not the case.

Mc: Probably because America is a world power, in a way, I mean the US specially and the UK is not that far behind, and they see how well they are doing in the world in all sort of respects, economically, politically, and how much influence they have and I think they view the language as a prestigious one, speaking English, specially in Macedonia is seen as something prestigious.

"In my country, we look up to American/English culture and that is the reason why English is infiltrating into my language".

Concerning cultural imperialism, the answers are more balanced and without significant differences. Nevertheless, it is interesting to see the comments that some individuals added in their questionnaires about this issue:

From where I come, the problem is not against the English as a powerful language, actually the problem is against the US and I mean American culture.

The point is the movies and the media that forced the spread the English language. Also, economy has an effect.

It wasn't the language that made itself unavoidable, but it was the developments in professional terms that made the language unavoidable... It wasn't the language that was imperialist, it was a professional imperialism, only than the language of the imperialist country became imperialist over other languages.

Students especially are encouraged to study it even if there is some concern about the English "culture" very popular now with the teenagers.

The interviews also show this trend. Most of the reporters seem to distinguish between language and culture. The important point is that it is the culture and the Discourse behind English that is imperialistic, and not the language itself. 
I: And you think that the culture is imperialistic?

It: Well yes, in some point become like the Americans, obviously.

I: How, how, in which aspects?

It: In everything of your life, I think, from the small things, from how your eat, how you think, how you dress, and when you watch t.v. you watch American movies predominantly, and everything.

Ch: Yeah for the culture cos Chinese people we had our culture for long time, so it's very difficult to say influence from English. But I think we have been changed but not for the language.

Only the speaker from Rwanda seems to identify more closely both concepts:

Rw: It's a great problem with lots of African children who don't know more their language, their culture also because: we haven't been exposed that much, went to English schools, studied English, you know, we know pop music and that sort of thing, you really are not exposed in the media to your own language and culture as much as you'd want to.

Rw: There's an interest in that for England and France to have people around the world speak their language because it's an adoption of their culture and so they'll, it'll be easier for them.

$\mathrm{Z}$ : Yea that's a bit tricky. I think English is influencing the society at firstly.

All this information supports the idea that there is a Discourse imperialism.

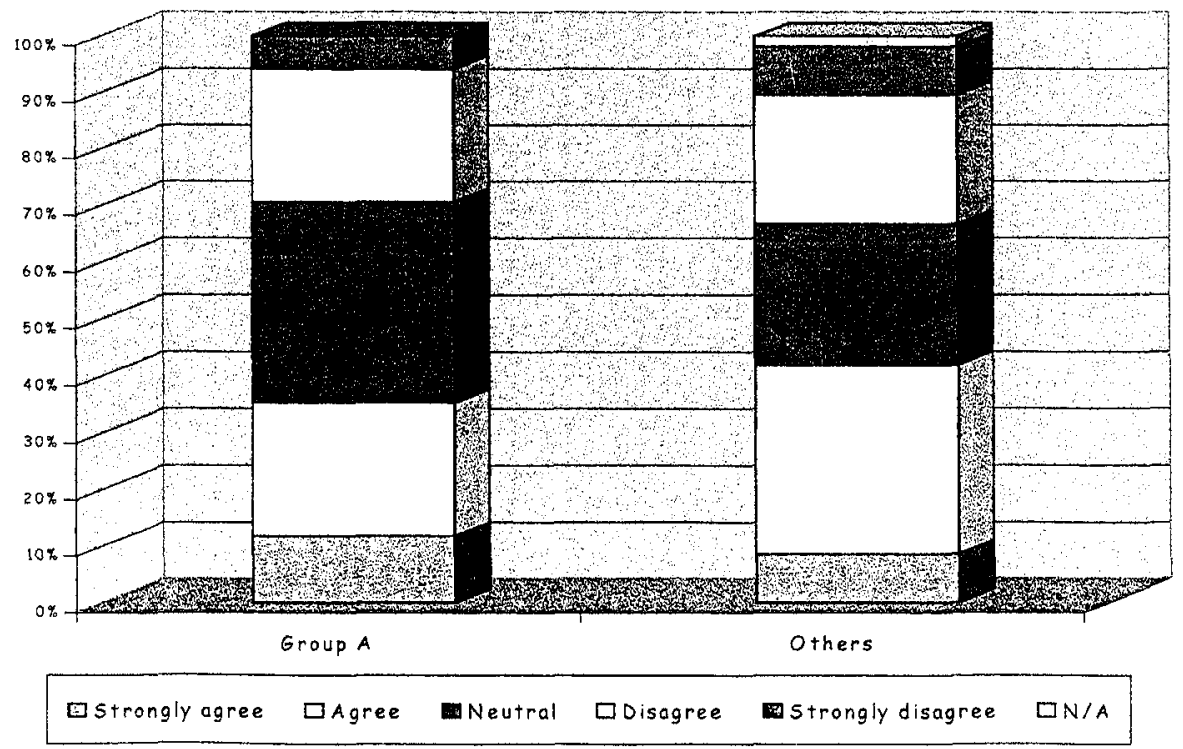


There is a clearer positioning in the second column, whereas informants belonging to Group A tended to remain neutral. People were keener on showing their attitudes in the interviews than in the questionnaires.

Mx: El idioma no, la cultura sí. Mx: Not the language but the culture.

Rw: The language is a vehicle for a cultural imperialism it's about to exporting English ideas, and by teaching them English is the first step, and then, the next step is the English culture.

\subsection{English: harmful or beneficial?}

- If people can feel discriminated, in one way or the other, because of English, then, why do they still want to learn it?

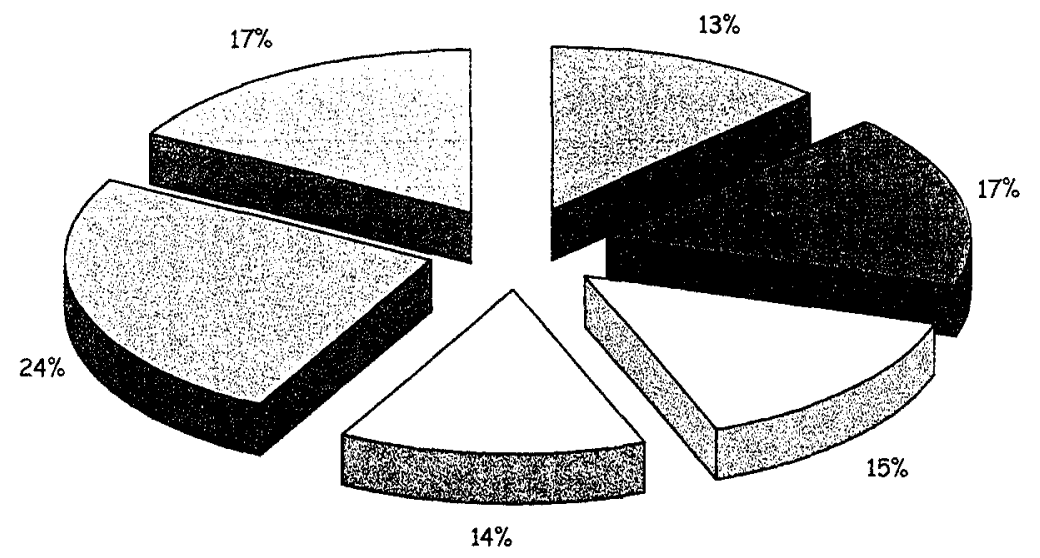

\begin{tabular}{|ll|}
\hline To get to know a different culture & Love for languages \\
$\square$ for travelling & $\square$ To study abroad \\
$\square$ Because it is useful in our world nowadays & $\square$ To irmprove my career
\end{tabular}

It seems that people learn English mainly for professional reasons: a good command of English is an important asset nowadays in the job market. Therefore, it could be argued that people, in general, do not opt freely to learn English, as Ngugi (1993) pointed out, but see it as something necessary -EFL, if not compulsory -ESL.

- "English has been very helpful to me in my career". 

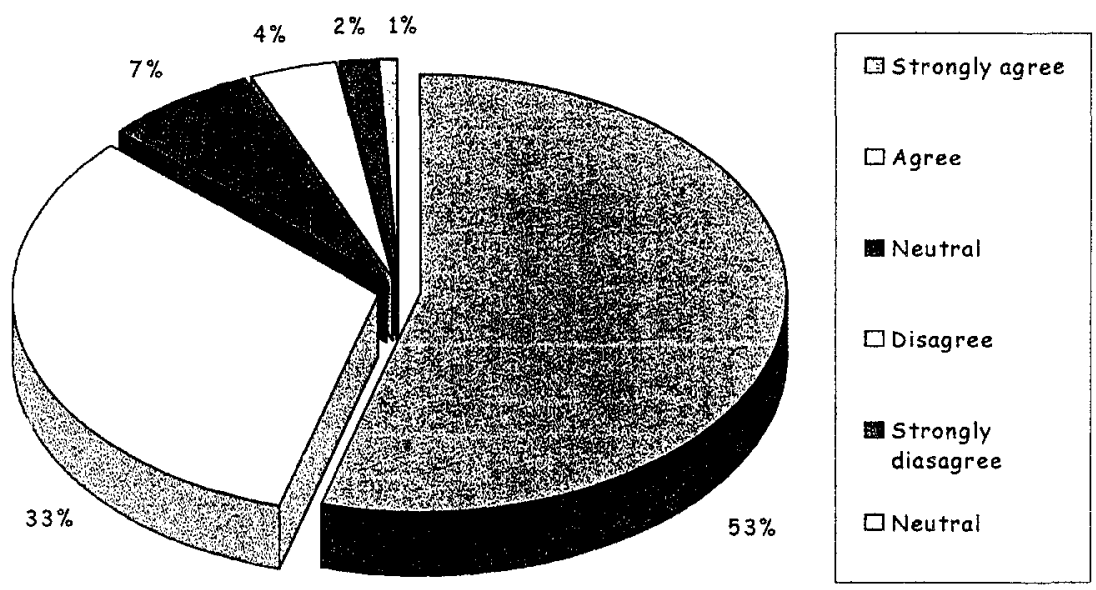

Even when people may show some resentment about the power of English and the US in the world, they have somehow profited from it. This explains the lack of eagerness seen in some answers to change the current situation. It is important to remember, however, that we are dealing with an elite and with people who have succeeded in studying English or through English. Not all those who study English today in the world might have benefited from it in the same way. The interviews reveal the same pattern:

S: And I managed to make a good career, I got a good job in the past, and maintain very good position, and so far I progressed and now I'm doing teaching as well and I think that yes, definitely.

Mc: (...) Thanks to my knowledge of English I've managed to achieve what I've achieved, a master's level and a PhD.

Re: Yes, definitely. I've got a job, I think it's money, first of all and on the learning point of view, I mean it's quite personal, I mean it was a kind of a challenge and it just all weird and oh: I mean, exciting things, to be able to think in another language, you know, it's just really nice and really good.

- When talking about how harmful English has been to them or their countries, the informants answered the following:

Mc: At the moment in Macedonia you can hardly get a job if you don't speak English, even for the simplest job, mechanical or whatever. So in that way I think it disadvantages a lot of people, specially people who have lost their jobs due to the recession we had and were 
redundant, and people who are in their mid 40s or 50s and for who learning a new language at that age, wasn't an easy thing to do, and: sometimes not financially liable, who: I think are really struggling because I think even though they have the skills, they don't speak English.

Singapore (Sing): (...) By having English as a first language it puts us in advantage say when we start working and stuff like that.

Z: I won't say it's been harmful, it's been able to mix up with the local, with the outside world it's been quite helpful.

Ch: For the English, for the language itself I: don't think it's harmful bu:t maybe for just the consumerism or and the economy, maybe were harmful to my country.

Rw: I don't think so because it's allowed my country to go beyo:nd its own borders, I mean, no country can be self-sufficient to international trade, you know, it's essential. So it's allowed a lot, it's allowed me to have an education that I wouldn't have before, it's allowed a lot of people to gain a lot of things and take advantage of the facilities available in you know in England, and other countries that speak different languages. So I don't think it's been that negative, no.

\section{Discussion}

\subsection{English as an international language}

Although scholars in general give a balanced account of how English has become an international language, with the discrepancies we have seen, the participants in this research do not seem to have a uniform opinion. If a country is to be considered as the main agent of its spread, that is the United States. This criticism generally comes from European or South American people who have good knowledge of the globalisation phenomenon and its consequences, but not from people belonging to Group A countries.

Many people ignore the events which took place during the British rule and at the end of the $19^{\text {th }}$ century, and only recognise the magnitude power of the US nowadays, under a new form of colonialism. Still, there is agency occurring nowadays, and it is two-sided: it comes, on the one hand, from leading countries, which create a Discourse were English is essential. We are talking about imperialism at a higher level, as has been seen, and lack of knowledge of English limits the access to that Discourse, both to understand it and to revert it. On the other hand, the response which is produced on Third World Countries which were former British colonies should not be ignored neither. A better understanding of this, together with a more a critical knowledge of those political facts can be helpful to be aware of the present and change current unfair trends.

The complot theory, as suggested, although no clearly stated, in Phillipson's work (1992) does not seem to be generally accepted, neither by the scholars nor by the 
participants, nor is it by us. As has been seen in this research, there is a mixture of factors that lead to erroneous consequences (language disappearance, identity problems, unfair situations in education, lack of Linguistic Human Rights...) but no complot should be acknowledged behind these. All these problems should be counteracted, at the same time as rising people's awareness of them.

\subsection{Imperialism}

"Like any sort of power, linguistic power may be positive or negative, beneficial or exploitative" (Kachru and Nelson, 1996: 87), but it seems that popular culture, Discourse in general, is more powerful. Even when the data shows that the US culture is not truly appreciated, the influence it has on the media, academic fields and on the popular culture, and more significantly, on the military and economic spheres, is recognised by many. Nevertheless, it has further consequences in every aspect of our lives, as the Italian informant said, and most importantly on English language. Informants who do not belong to Group A countries seem to be more eager to announce this tendency.

The role of films, media, and information is paramount. They form part of the Discourse which is influencing cultures all over the world. In fact, Britain nowadays is borrowing more and more words from the American lexicon (e.g. guy, bloke, cab; the tendency to shorten words -vocab., combo, cosy, presi; the propensity to adapt the spelling to the pronunciation -tonite, color, ...), and this might suggest that the culture, and not the language, is the dominating factor, as many informants suggested in their responses.

\section{Conclusions}

No language should be considered imperialistic, nor sexist or racist. It is only a mirror reflecting the structure behind it and we should rather talk of Discourse Imperialism, as Pennycook suggests. English, then, could be a useful tool if it is learned additively within the frame of "language ecology". The participants seem to share this point of view, but their opinions cannot be considered straightforward and homogeneous. There is a tendency to melt together tradition and modernity and, although some of the negative effects that English has are acknowledged by some, they all recognize that English has empowered them. But this might not be the case for all students of English in the world. Further research should analyse the attitudes of those who have not benefited from English, but who, contrarily, might consider it a waste of time, money and energy.

Considering the role of English as an International Language, it is understandable that native speakers of English, as any other community would do, want to safeguard their language. Nevertheless, English, when used at international level, should be detached from any given country or cultural norm. Further research should concentrate on English as an International Language, whether it is something different from all these varieties, as BruttGriffler suggests (2002) or if its has room in itself for all of them. The possibilities that 
Esperanto offers should not be disregarded, as a language which offers psychological advantages, equal possibilities to all its speakers and which is politically correct. The capacity for each individual, whatever their background, to express themselves through an International language is not to be underestimated. As far as English is concerned, if it belongs to those who speak it at any level, its use as an international language in the world should benefit all its users and not just a few.

We would like to finish by quoting Ngugi (1993: 40), "when there is real economic, political and cultural equality among nations and there is democracy, there will be no reason for any nation, nationality, or people to fear the emergence of a common language... English would make a credible candidate". Within such a frame, we would not contemplate different varieties of a language, but different discourses in English (Pennycook, 1994).

\section{Notes}

1. Teaching English to Speakers of Other Languages.

2. Due to space limitations, we will only present the relevant information for this paper. Interview transcriptions have been edited to avoid repetitions and hesitations.

3. "What is the public attitude in your country to the fact that English is such a powerful language?"

4. "Nowadays, those who do not speak English have little prospect of success".

\section{Works Cited}

Brutt-Griffler, Janina (1998): "Conceptual questions in English as a world language: taking up an issue". World Englishes 17(3): 381-392.

. (2002): World English. London: Multilingual Matters.

Canagarajah, A. Suresh. (2000): "Negotiating ideologies through English: strategies from the periphery". In T. Ricento (ed.) Ideology, Politics and Language Policies. Focus on English. Impact 6. Studies in Language and Society. Philadelphia: John Benjamins, 121-132.

Crystal, David (1988) The English Language. Harmondsworth: Penguin Books. (1997): English as a Global Language. Cambridge: Cambridge University Press.

Davies, Alan (1989): "Is International English an Interlanguage?". TESOL Quarterly 23(3): $447-467$.

. (1996): "Ironising the Myth of Linguicism". Journal of Multilingual and Multicultural Development 17(6): 485-496.

Fairclough, Norman (1989): Language and Power. Essex, England: Longman Group. (ed.)(1992a): Critical Language Awareness. Essex: Longman.

. (1992b): Discourse and Social Change. Cambridge: Cambridge University Press.

(1995): Critical Discourse Analysis. Essex: Longman.

González Fernández, Paula (2004): “Linguistic imperialism in the ELT profession?". Vial 1: $113-150$.

González, Antonio and Paula González (2004): "El imperialismo lingüístico". In Agenda 
Latinoamericana 2005, 44-45, Comité Oscar Romero, Gorfisa, Zaragoza. Greenbaum, Sidney (1985): "Issues and Implications". In S. Greenbaum (ed.) The English Language Today. Oxford: Pergamon, 1-6.

Holborow, Marnie (1992): "Linguistic imperialism". ELT Journal 47(4): 358-361.

Kachru, Braj B. (1981): “The pragmatics of non-native varieties of English". In L.E. Smith (ed.) English for Cross-Cultural Communication. London: Macmillan Press, 15-39.

(1986): "Standards, codification and sociolinguistic realism: the English language in the outer circle". In R. Quirk and H. Widdowson (eds.) English in the World. Cambridge: Cambridge University Press in association with the British Council, 11-30.

. (1992): "Models for non-native Englishes". In Kachru (ed.) The Other Tongue: English across Cultures. Oxford: Pergamon Press , 48-74.

Kachru, Braj B. and Cecil L. Nelson (1996): "World Englishes". In S.L. McKay and N.H. Hornberger (eds.) Sociolinguistics and Language Teaching. Cambridge: Cambridge University Press, 71-102.

McArthur, Tom (1998): The English Languages. Cambridge: Cambridge University Press. McKay, Sandra Lee (2002): Teaching English as an International Language. Oxford: OUP.

Ngugi, wa Thiong'o (1993): Moving the Centre. The Struggle for Cultural Freedoms London: James Currey Ltd.

Pennycook, Alastair (1994): The Cultural Politics of English as an International Language. London: Longman.

. (1995): "English in the World/the World in English". In J.W. Tollefson (ed.) Power and Inequality in Language Education. Cambridge: Cambridge University Press, 34-58.

. (1998): English and the Discourses of Colonialism. London: Routledge.

. (2000a): "Language, ideology and hindsight: lessons from colonial language policies". In T. Ricento (ed.) Ideology, Politics and Language Policies. Focus on English. Impact 6. Studies in Language and Society. Philadelphia: John Benjamins, 49-66.

. (2000b): "English, politics, ideology: from colonial celebration to postcolonial performativity". In T. Ricento (ed.) Ideology, Politics and Language Policies. Focus on English. Impact 6. Studies in Language and Society. Philadelphia: John Benjamins, 107-120. . (2000c): "The social politics and the cultural politics of language classrooms". In J.K. Hall and W.G. Eggington (eds.) The Sociopolitics of English Language Teaching. London: Multilingual Matters, 89-103.

Phillipson, Robert (1988): "Linguicism: structures and ideologies in linguistic imperialism". In T. Skutnabb-Kangas and J. Cummins (eds.) Linguistic Genocide in Education-or Worldwide Diversity and Human Rights? New Jersey: Lawrence Erlbaum Associates, 339-358.

(1992): Linguistic Imperialism. Oxford: OUP

Phillipson, Robert (2000): "English in the New World Order: Variations on a theme of Linguistic Imperialism and "World" English". In T. Ricento (ed.) Ideology, Politics and Language Policies. Focus on English. Impact 6. Studies in Language and Society. Philadelphia: John Benjamins, 87-106.

Phillipson, Robert and Tove Skutnabb-Kangas (1996): "English only world-wide or language ecology?". TESOL Quarterly 30(3): 429-453.

Redish, Janice C. (1985): The Plain English Movement. In S. Greenbaum (ed.) The English Language Today. Oxford: Pergamon, 125-138.

Ricento, Thomas (1994): "Review of Linguistic Imperialism". TESOL Quarterly 28: 421-427. 
Romaine, Suzanne (1992) (1989): Bilingualism. Oxford: Blackwell.

Skutnabb-Kangas, Tove (2002): "Linguistic human rights in education and Turkey -some international comparisons". International Conference on Kurds, the European Union and Turkey, Copenhagen, Denmark, $14^{\text {th }}$ October 2002.

Skutnabb-Kangas, Tove and Jim Cummins (eds.)(1988): Minority Education: from Shame to Struggle. Avon: Multilingual Matters.

Tollefson, James W. (2000): "Policy and ideology in the spread of English". In J.K. Hall and W.G. Eggington (eds.) The Sociopolitics of English Language Teaching. London: Multilingual Matters, 7-21.

Widdowson, Henry G. (1994): The Ownership of English. TESOL Quarterly 28: 377-388. 146. . (1997): "EIL, ESL, EFL: global issues and local interests". World Englishes 16(1): 135-

Ethnologue. (2005): < www.ethnologue.com> US English, Inc. (2005): <www.us-english.org>

\section{APPENDIX 1}

\section{PART A}

Name:

Age:

Nationality:

Profession:

Which language/s do you speak?

Since when have you been learning English?

If living in the UK, how long have you been here for?

\section{PART B}

Mark with an $\mathrm{X}$ accordingly to what you most strongly agree with.

1) The best teacher of English is a native speaker.

\begin{tabular}{|c|c|c|c|c|}
\hline Strongly agree & Agree & Neutral. & Disagree & Strongly disagree \\
\hline & & & & \\
\hline
\end{tabular}

2) All children in my country should learn English from an early age.

\begin{tabular}{|c|c|c|c|c|}
\hline Strongly agree & Agree & Neutral. & Disagree & Strongly disagree \\
\hline
\end{tabular}

3) When learning English, no other languages should be used in the classroom.

\begin{tabular}{|c|c|c|c|c|}
\hline Strongly agree & Agree & Neutral. & Disagree & Strongly disagree \\
\hline & & & & \\
\hline
\end{tabular}

4) English should be employed in schools in my country as the language through which teaching and learning of other subjects takes place. 


\begin{tabular}{|c|c|c|c|c|}
\hline Strongly agree & Agree & Neutral. & Disagree & Strongly disagree \\
\hline & & & & \\
\hline
\end{tabular}

5) My mother tongue (or other languages I know) has helped me to learn English.

\begin{tabular}{|c|c|c|c|c|}
\hline Strongly agree & Agree & Neutral. & Disagree & Strongly disagree \\
\hline
\end{tabular}

6) I am proud of keeping my foreign "accent" when speaking English.

\begin{tabular}{|c|c|c|c|c|}
\hline Strongly agree & Agree & Neutral. & Disagree & Strongly disagree \\
\hline & & & & \\
\hline
\end{tabular}

7) English should be used in other domains in my country: advertising, on the TV or radio...

\begin{tabular}{|c|c|c|c|c|}
\hline Strongly agree & Agree & Neutral. & Disagree & Strongly disagree \\
\hline & & & & \\
\hline
\end{tabular}

8) English is affecting the vocabulary and the grammar of my native language in a negative way. \begin{tabular}{|c|c|c|c|c|}
\hline Strongly agree & Agree & Neutral. & Disagree & Strongly disagree \\
\hline & & & & \\
\hline
\end{tabular}

9) Whenever a new concept/invention appears, a new word should be created in my language instead of using the English word.

\begin{tabular}{|c|c|c|c|c|}
\hline Strongly agree & Agree & Neutral. & Disagree & Strongly disagree \\
\hline & & & & \\
\hline
\end{tabular}

10) Learning English broadens your mind

\begin{tabular}{|c|c|c|c|c|}
\hline Strongly agree & Agree & Neutral. & Disagree & Strongly disagree \\
\hline
\end{tabular}

11) English has been very helpful to me in my career.

\begin{tabular}{|c|c|c|c|c|}
\hline Strongly agree & Agree & Neutral. & Disagree & Strongly disagree \\
\hline & & & & \\
\hline
\end{tabular}

12) Nowadays, those who do not speak English have little prospect of success.

\begin{tabular}{|c|c|c|c|c|}
\hline Strongly agree & Agree & Neutral. & Disagree & Strongly disagree \\
\hline
\end{tabular}

13) The economic and military power of the USA is the main reason for the rapid spread of English

\begin{tabular}{|c|c|c|c|c|}
\hline Strongly agree & Agree & Neutral. & Disagree & Strongly disagree \\
\hline & & & & \\
\hline
\end{tabular}

14) English and American people are arrogant about their language.

\begin{tabular}{|c|c|c|c|c|}
\hline Strongly agree & Agree & Neutral. & Disagree & Strongly disagree \\
\hline & & & & \\
\hline
\end{tabular}

15) English is dominating and undermining other languages. 


\begin{tabular}{|c|c|c|c|c|}
\hline Strongly agree & Agree & Neutral. & Disagree & Strongly disagree \\
\hline & & & & \\
\hline
\end{tabular}

16) In my country, we look up to American/English culture and that is the reason why English is infiltrating into my language.

\begin{tabular}{|c|c|c|c|c|}
\hline Strongly agree & Agree & Neutral. & Disagree & Strongly disagree \\
\hline & & & & \\
\hline
\end{tabular}

17) English is an imperialistic language

\begin{tabular}{|c|c|c|c|c|}
\hline Strongly agree & Agree & Neutral. & Disagree & Strongly disagree \\
\hline & & & & \\
\hline
\end{tabular}

\section{PART C}

Please, answer the following questions:

1) Is English used in your country as the language in school for teaching and learning other subjects?

If yes, answer:

a) From which level? (Primary, Secondary, High School, University)

b) Do you agree with that?

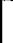

c) What is the public attitude in your country towards this (learning in English)?

2) What is the public attitude in your country to the fact that English is such a powerful language?

3) For which reasons did you start learning English?
a) Love for languages
b) To get to know a different culture
c) For travelling
d) To study abroad
e) Because it is useful in our world nowadays
f) To improve my career.
g) Other (please, specify): 
4) How do you translate these words into your language?:

-computer

-football

-political meeting

-email

-camping site

\section{THANKS FOR YOUR COLLABORATION!}

\section{APPENDIX 2}

1. Which country are you from?

2. Which languages do people normally speak in your country?

a. At what age do people normally start learning English? Who teaches them (native speakers)? Do you agree with that?

3. Who uses English? In which situations?

4. Is English present in the media? To which extent? What do you think of it?

5. Is English present in the educational system? To which extent? What do you think of it?

a. What do people in your country think about it? Are they resentful, resigned, proud...?

b. Which kind of English is it? Do you give it a special name? Is it similar to Standard British English?

6. When did you start learning English? Why?

7. As a non-native, do you think that you should be judged in accordance to your use of Standard English or to your own particular variety?

8. Do you think that English should be, or is, the language for international communication? Should there be any other one? If it were English, should it be Standard English? Should we accept any variety or a given International English?

9. Here in England, have you ever been discriminated because of your accent/use of English? How? How did you feel about it?

10. Do you think English can be a means of discrimination? In which sense?

11. Do you feel identified with your mother tongue?

a. Do you think that local languages like yours should be protected and used in education? (many are in danger of death) Or do you think that using English would be more beneficial for you/your country?

12. Is English influencing your mother tongue? How? Why do you think that is happening? (e.g. influence of popular culture, international politics...) How do you feel about it?

13. Do you think that by using English, here in England, you are thinking the way English people think? Or do you still keep your ways of thinking, probably more related to your mother tongue/culture?

14. Do certain words/expressions have more meaning for you if you say them in your mother tongue? Or can you express yourself totally in English?

15. Do you think that the spread of English has in any way been harmful to your society, or to the world? In which ways?

16. Do you think that English has been beneficial for you? In which ways? 


\section{APPENDIX 3}

My name is Paula Gonzalez Fernandez and I am currently doing a MA in Applied Linguistics at the University of Sheffield.

This questionnaire you have received is going to be the most important data for my MA dissertation.

Although it might not seem so, it does not take very long to answer it. Just fill it in and send it back to me in an email as an attachment. I am asking you some personal details in it, but this is only for oetter organisation. Privacy will be kept to a maximum in the dissertation.

I would also appreciate it very much if you could forward it to your friends/relatives. It does not matter where they are from, as long as they are non-native speakers of English. All they have to do is email it back to me again.

My email address is egp01pg@sheffield.ac.uk.

Thank you very much in advance for your help and your time. I really appreciate it.

\section{Paula Gonzalez Fernandez}

\section{APPENDIX 4}

EFL: English as a Foreign Language.

I: interviewer.

EIL: English as an International Language.

It: Italy.

ELT: English Language Teaching.

Mc: Macedonian.

ESL: English as a Second Language.

Mx: Mexico.

NNS: Non Native Speaker.

NS: Native Speaker.

Re: Isle Réunion.

Rw: Rwanda.

TESOL: Teaching English to Speakers of Other Languages.

S: Syria.

Sing: Singapore.

Ch: China.

Z: Zimbabwe.

Fr: France.

\section{Transcriptions:}

: elongated sound .

(...) stretch of speech not transcribed. 